Paper

\title{
Preparation of $\mathrm{Eu}^{2+}$-doped $\mathrm{Ca}_{2} \mathrm{Si}_{5} \mathrm{~N}_{8}$ by Carbothermal Reduction I Nitridation of Spray-pyrolyzed Oxide/nitride Powder and Its Luminescence Properties
}

\author{
Kazuaki YAMAGUCHI*, Hubertus T. HINTZEN**, Anne C. A. DELSING**, Hideki KUWAHARA**, \\ Seiichiro KODA* and Kiyoshi ITATANI*
}

* Sophia University, Department of Materials and Life Sciences, Faculty of Science and Engineering
** Eindhoven University of Technology, Department of Chemical Engineering and Chemistry
*** Sophia University, Department of Engineering and Applied Sciences, Faculty of Science and Engineering

Received April 18, 2011, Accepted October 5, 2011

\begin{abstract}
The conditions for the preparation of regular-shaped $\mathrm{Eu}^{2+}$-doped calcium silicon nitride $\left(\left(\mathrm{Ca}_{0.99} \mathrm{Eu}_{0.01}\right)_{2} \mathrm{Si}_{5} \mathrm{~N}_{8}\right)$ powder were examined by the carbothermal reduction and nitridation (CRN) of oxide/nitride powder prepared by ultrasonic spray pyrolysis. Two kinds of silicon sources, i.e., (i) colloidal silica (CS) and (ii) silicon nitride $\left(\mathrm{Si}_{3} \mathrm{~N}_{4}\right.$; $\left.\mathrm{SN}\right)$, were used for the spray pyrolysis. Firstly, the solution containing $0.057 \mathrm{~mol} \cdot \mathrm{dm}^{-3} \mathrm{Ca}\left(\mathrm{NO}_{3}\right)_{2}, 0.140 \mathrm{~mol} \cdot \mathrm{dm}^{-3} \mathrm{CS}$ and $5.71 \times 10^{-4}$ $\mathrm{mol} \cdot \mathrm{dm}^{-3} \mathrm{Eu}\left(\mathrm{NO}_{3}\right)_{3}$ was spray-pyrolyzed at $600^{\circ} \mathrm{C}$, and the resulting powder was calcined at $800^{\circ} \mathrm{C}$ for $10 \mathrm{~min}$ in air. The single phase but agglomerated particles of $\left(\mathrm{Ca}_{0.99} \mathrm{Eu}_{0.01}\right)_{2} \mathrm{Si}_{5} \mathrm{~N}_{8}$ were obtained when the $\mathrm{CRN}$ (the relative carbon amount to the stoichiometric amount $(m): 1.5$ ) of spray-pyrolyzed/calcined oxide powder was conducted at $1300^{\circ} \mathrm{C}$ for $2 \mathrm{~h}$ in nitrogen $\left(\mathrm{N}_{2}\right)$ atmosphere. Secondly, the solution containing $0.0285 \mathrm{~mol} \cdot \mathrm{dm}^{-3} \mathrm{Ca}\left(\mathrm{NO}_{3}\right)_{2}, 0.070 \mathrm{~mol} \cdot \mathrm{dm}^{-3} \mathrm{SN}$ and $2.855 \times 10^{-4} \mathrm{~mol} \cdot \mathrm{dm}^{-3} \mathrm{Eu}\left(\mathrm{NO}_{3}\right)_{3}$ (one-half of the solution concentration compared to the case of CS utilization) was spray-pyrolyzed, and the CRN of spray-pyrolyzed oxide/nitride powder was conducted at $1500^{\circ} \mathrm{C}$ for $2 \mathrm{~h}$ to obtain $\left(\mathrm{Ca}_{0.99} \mathrm{Eu}_{0.01}\right)_{2} \mathrm{Si}_{5} \mathrm{~N}_{8}$ in $\mathrm{N}_{2}$ atmosphere. The microscopic observation showed that this powder was composed of regular-shaped particles with sizes of approximately 2-3 $\mu \mathrm{m}$. The excitation and emission peaks of this powder appeared at around 370 and $590 \mathrm{~nm}$, respectively, showing the emission of orange light.
\end{abstract}

\section{KEYWORDS: calcium silicon nitride, carbothermal reduction/nitridation, regular particle shape, luminescence}

\section{Introduction}

A light emitting diode (LED) is a promising illumination source of the next generation. Compared to the most popular fluorescent lamp currently used in our life, it has noted advantages of energy saving, long operation life and mercury free ${ }^{1)}$. The commercial white-LED generally consists of a blue emitting LED and a yellow-emitting phosphor (e.g., Ce-doped yttrium aluminate garnet $\left(\mathrm{Y}_{3} \mathrm{Al}_{5} \mathrm{O}_{12}\right)$; YAG:Ce) and, therefore, has problem of poor red components ${ }^{2}$. Recently, many researchers pay attention to the nitride phosphors from the viewpoints of (i) absorption of visible light and emission of longer wavelength light, and (ii) excellent thermal and chemical stabilities $^{3}$. However, the synthesis of nitride powder generally requires the heating operation at higher temperature, compared to the case of oxide and sulfide phosphors; moreover, the powder consists of irregularshaped particles with wide size distribution.

$\mathrm{Eu}^{2+-}$ doped calcium silicon nitride $\left(\left(\mathrm{Ca}_{1}{ }_{x} \mathrm{Eu}_{x}\right)_{2} \mathrm{Si}_{5} \mathrm{~N}_{8}\right)$ phosphor, which has three dimensional networks consisting of a $\mathrm{SiN}_{4}$-based tetrahedral structure, is a promising material as an orange emitting component in white-LED ${ }^{45)}$. The phosphor particles are mainly prepared by the solid-state reaction of nitride compounds, e.g., $\mathrm{Ca}_{3} \mathrm{~N}_{2}$ and $\mathrm{Si}_{3} \mathrm{~N}_{4}$ or carbothermal reduction and nitridation (CRN) of oxide/nitride compounds ${ }^{6}$. The technique of solid state reaction may have the advantage to control the chemical composition but some problems on the high-purity, chemical homogeneity at the atomic level, regular particle shape, and homogeneous distribution of activator ions in the host material.

On the other hand, ultrasonic spray pyrolysis (USP) is a technique to instantaneously form the particles through (i) the introduction of droplets with a homogeneous mixture of the desired kinds and amounts of components in the heating zone, (ii) the precipitation of solid materials due to the evaporation of solvent, and (iii) the solid-state reaction among the solidified materials ${ }^{788}$ ). The resulting powder has the noted luminescence properties, reflecting the characteristics of spray pyrolysis ${ }^{9110)}$. The nitridation of oxide powder is further expected to be promoted using the powder prepared by USP, because the oxide powder is 
composed of nanometer-sized particles containing homogeneously dispersed chemical components. On the basis of such background, this paper describes the research on the preparation of regular-shaped $\left.\left(\mathrm{Ca}_{1 \times} \times \mathrm{Eu}_{x}\right)_{2} \mathrm{Si}_{5} \mathrm{~N}_{8}(x=0.01)\right)$ particles through the combination of USP and CRN techniques.

\section{Experimental procedure}

The objective compound, i.e., (Ca0.99 $\left.\mathrm{Eu}_{0.01}\right)_{2} \mathrm{Si}_{5} \mathrm{~N}_{8}$, was prepared by the combination of USP and CRN techniques. Two kinds of silicon sources, i.e., (i) colloidal silica (CS) and (ii) silicon nitride $\left(\mathrm{Si}_{3} \mathrm{~N}_{4} ; \mathrm{SN}\right)$, were used for the spray pyrolysis. The kinds and concentrations of starting materials with the chemical composition of $(\mathrm{Ca}+\mathrm{Eu}) / \mathrm{Si}$ $=0.40$ are shown in Table 1 . The solution was sprayed using a vibrator with the frequency of $2.4 \mathrm{MHz}$ and introduced into a furnace kept being heated at $600^{\circ} \mathrm{C}$. The droplets were changed into solid materials, due to the evaporation of water vapor and the solid state reaction of precipitated metal salts ${ }^{788}$, and the powder was collected by filter paper. The resulting powder was calcined at $800^{\circ} \mathrm{C}$ for $10 \mathrm{~min}$ in air (Sample code: SP(CS)), or was used with no calcination (Sample code: SP(SN-1.0) and SP(SN$0.5)$ ). These oxide/nitride powders were mixed with carbon (the relative carbon amount to the stoichiometric amount (m): 1.5) and then the CRN treatment was conducted under the optimum heating conditions ranging from 900 to $1600^{\circ} \mathrm{C}$ for $2 \mathrm{~h}$ in $\mathrm{N}_{2}$ atmosphere.

Crystalline phases were identified using an X-ray diffractometer (XRD; RINT2100V/P, Rigaku, Tokyo) with monochromatic $\mathrm{CuK} \alpha$ radiation generated at $40 \mathrm{kV}$ and $40 \mathrm{~mA}$. The morphology of the particles was observed using a field-emission scanning electron microscope (FESEM; SU-8000, accelerating voltage, $5 \mathrm{kV}$, Hitachi, Tokyo), after the particles had been coated with Pt-Pd in order to avoid charging effects. The chemical composition of the powder prepared by various techniques was examined using SEM/energy dispersive electron microanalyzer (EDX; E-1030). The photoluminescence spectra were measured using a fluorescent sprectrophotometer (F-4500, Hitachi, Tokyo).

Table 1 Preparation conditions of the starting solutions for spray pyrolysis (total amount of solution: $250 \mathrm{~cm}^{3}$ )

\begin{tabular}{|c|c|c|c|c|}
\hline Sample & $\mathrm{Ca}\left(\mathrm{NO}_{3}\right)_{2}$ & Colloidal silica & $\mathrm{Si}_{3} \mathrm{~N}_{4}$ & $\mathrm{Eu}\left(\mathrm{NO}_{3}\right)_{3}$ \\
\hline Code & $\mathrm{mol} \cdot \mathrm{dm}^{-3}$ & $\mathrm{~mol} \cdot \mathrm{dm}^{-3}$ a) & $\mathrm{mol} \cdot \mathrm{dm}^{-3}$ & $\mathrm{~mol} \cdot \mathrm{dm}^{-3}$ \\
\hline SP(CS) & 0.057 & 0.140 & & $5.71 \times 10^{-4}$ \\
\hline $\mathrm{SP}(\mathrm{SN}-1.0)$ & 0.057 & & 0.140 & $5.71 \times 10^{-4}$ \\
\hline SP(SN-0.5) & 0.0285 & & 0.070 & $2.855 \times 10^{-4}$ \\
\hline
\end{tabular}

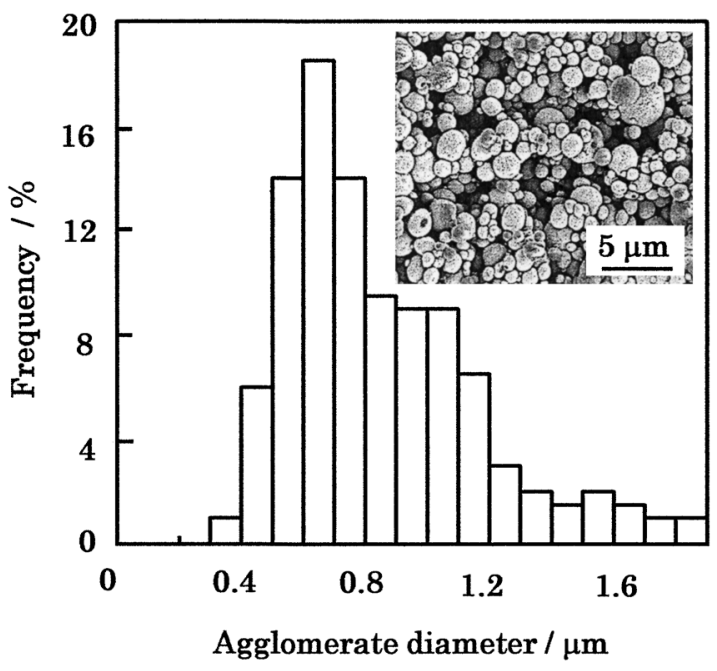

Figure 1 FE-SEM micrograph and agglomerate diameter distribution of the powder spray-pyrolyzed at $600^{\circ} \mathrm{C}$, using $\mathrm{SP}(\mathrm{CS})$

\section{Results and discussion}

\subsection{Preparation of $\left(\mathrm{Ca}_{0.99} \mathrm{Eu}_{0.01}\right)_{2} \mathrm{Si}_{5} \mathrm{~N}_{8}$ from $\mathrm{SP}(\mathrm{CS})$}

The preparation conditions of $\left(\mathrm{Ca}_{0.99} \mathrm{Eu}_{0.01}\right)_{2} \mathrm{Si}_{5} \mathrm{~N}_{8}$ from CS were examined by the combination of USP and CRN techniques. Firstly, FE-SEM micrographs of the spraypyrolyzed powders are presented in Figure 1, together with the agglomerate-diameter distributions. Note that the agglomerate-diameter distributions were examined measuring the diameters of 200 agglomerates by sliding calipers. These powders were composed of spherical agglomerates, and the mean particle diameter obtained from SP(CS) was $0.96 \mu \mathrm{m}$. These agglomerates must be reflected by the drop diameters sprayed using ultrasonic vibrator. The drop diameter ( $G_{\mathrm{DROP}}$ ) formed by the use of ultrasonic vibrator is calculated as follows ${ }^{11}$ :

$$
G_{\text {DROP }}=0.34\left[\frac{8 \pi \sigma}{\rho f^{2}}\right]^{\frac{1}{3}}
$$

where $\rho$ is the droplet density, $f$ is the frequency of the ultrasonic vibrator $(=2.4 \mathrm{MHz})$, and $\sigma$ is the surface tension. The use of an ultrasonic vibrator produces droplets with diameters of typically $2.3 \mu \mathrm{m}$. Since the mean agglomerate diameters of powders obtained by the spraypyrolysis of SP(CS) was below $1 \mu \mathrm{m}$, the solid agglomerate may be formed by the volume reduction due to the evaporation of water vapor from the droplets.

According to the XRD results, no marked compounds were detected from the spray-pyrolyzed powder. In order to check the phase changes during the heating, DTA-TG was conducted with the results being shown in Figure 2 . Based upon the DTA curve, the exothermic event of SP(CS) started to occur at around $900^{\circ} \mathrm{C}$. On the other hand, TG curve showed that the mass loss gradually occurred with temperature from 30 to $800^{\circ} \mathrm{C}$. The 


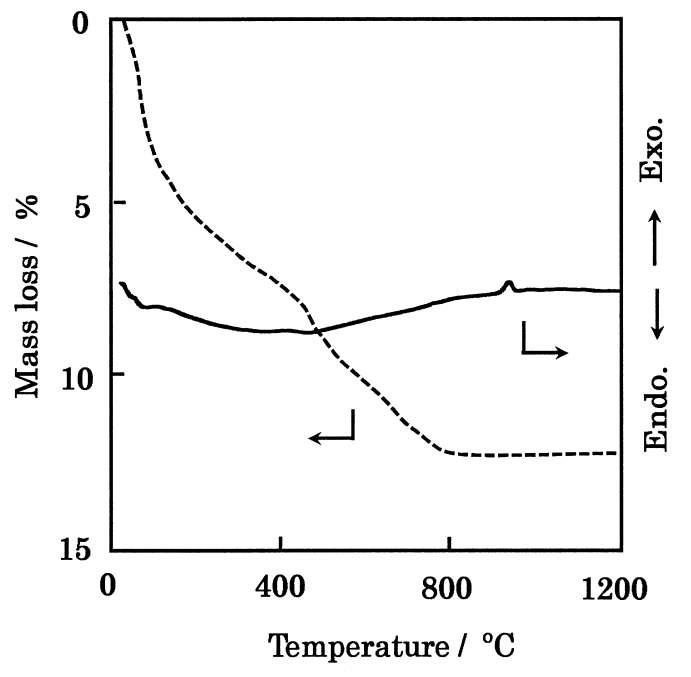

Figure 2 DTA-TG curves of the powder prepared by the spray-pyrolysis of SP(CS) in air (heating rate: $10^{\circ} \mathrm{C} \cdot \mathrm{min}^{-1}$ )

exothermic event occurring above $800^{\circ} \mathrm{C}$, therefore, must be related to the phase changes. In order to make clear the phase changes above $800^{\circ} \mathrm{C}$, the crystalline phase was checked by using an X-ray diffractometer. Figure 3 shows the XRD patterns of powder obtained by the spray pyrolysis of $\mathrm{SP}(\mathrm{CS})$ at $600^{\circ} \mathrm{C}$. No crystalline phase was detected, i.e., broad background over the $2 \theta$ range of 20 to $40^{\circ}$, from the powder heated at $800^{\circ} \mathrm{C}$. The reaction product, $\beta-\mathrm{CaSiO}_{3}$, was detected from the powders heated at 1000 and $1200^{\circ} \mathrm{C}$. Moreover, $\mathrm{SiO}_{2}$, as well as $\alpha \mathrm{CaSiO}_{3}$, were detected from the powder heated at $1300^{\circ} \mathrm{C}$. Since

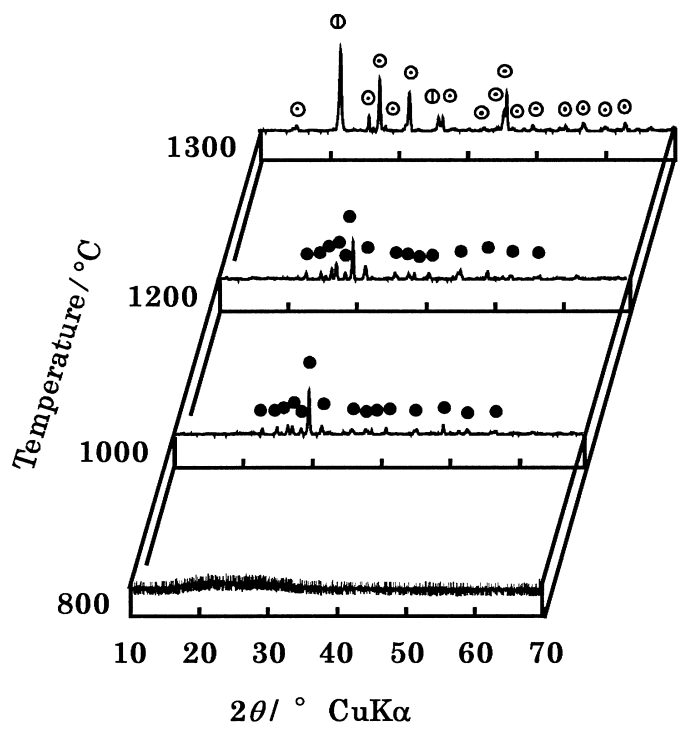

Figure 3 XRD patterns of the powders after the calcination of the powder prepared by the spray-pyrolysis of $\mathrm{SP}(\mathrm{CS})$ at $600^{\circ} \mathrm{C}$

๑: $\beta-\mathrm{CaSiO}_{3} \quad$ (JCPDS 42-550) $\bigcirc: \alpha-\mathrm{CaSiO}_{3}\left(31^{-}\right.$ 300) (1: $\mathrm{SiO}_{2}$ (JCPDS 39-1425)

Note that the calcination time was $10 \mathrm{~min}$ at each temperature in air. the $\beta-\mathrm{CaSiO}_{3}$ was detected from the powders heated at $1000-1200^{\circ} \mathrm{C}$, the exothermic event on the DTA curve $\left(900^{\circ} \mathrm{C}\right)$ may be attributed to the crystallization of amorphous material to $\beta-\mathrm{CaSiO}_{3}$ through the following chemical reaction:

$$
\mathrm{CaO}+\mathrm{SiO}_{2} \rightarrow \beta-\mathrm{CaSiO}_{3}
$$

The broad background in the $2 \theta$ range of 20 to $40^{\circ}$, which appeared in the XRD pattern at $800^{\circ} \mathrm{C}$, corresponds to the $\mathrm{X}$-ray reflection positions of $\mathrm{CaSiO}_{3}$. This fact indicates that $\mathrm{CaSiO}_{3}$ may have the possibility of being present as amorphous material at $800^{\circ} \mathrm{C}$. The $\mathrm{CRN}$ operation of amorphous material, i.e., the replacement of oxygen atom with nitrogen, is expected to be condcuted more homogeneously than that of crystalline material. On the basis of mass loss and amorphous state, the calcination of the powder obtained by the spray-pyrolysis of $\mathrm{SP}(\mathrm{CP})$ was conducted at a fixed temperature of $800^{\circ} \mathrm{C}$ for $10 \mathrm{~min}$.

Figure 4 shows the typical XRD patterns of the powders after the CRN treatment of spraypyrolyzed/calcined powder was conducted at each temperature for $4 \mathrm{~h}$. Note that the carbon amount $(\mathrm{m})$ added to the powder was fixed at 1.50 , on the basis of our preliminary investigation $(1.0 \leq m \leq 2.0)$. The crystalline phase of the powder $\mathrm{CRN}$-treated at $900^{\circ} \mathrm{C}$ for $4 \mathrm{~h}$ was only $\mathrm{C}$. The crystalline phases of the powder CRN-treated at $1100^{\circ} \mathrm{C}$ for $4 \mathrm{~h}$ were $\mathrm{C}$ and $\beta-\mathrm{CaSiO}_{3}$. The crystalline phase of the powder CRN-treated at 1300 and $1500^{\circ} \mathrm{C}$ was only $\mathrm{Ca}_{2} \mathrm{Si}_{5} \mathrm{~N}_{8}$.

Phase changes during the CRN treatment of spraypyrolyzed/calcined powder were examined on the basis of

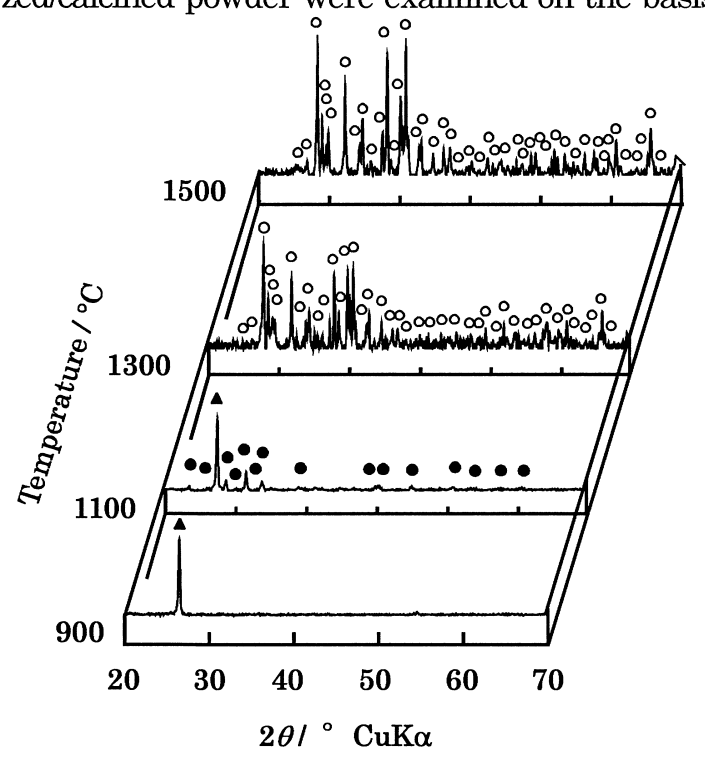

Figure 4 XRD patterns after the CRN treatment $(4 \mathrm{~h})$ of the spray-pyrolyzed / calcined powder ( $m: 1.5)$ O: $\mathrm{Ca}_{2} \mathrm{Si}_{5} \mathrm{~N}_{8}$ (JCPDS 82-2489)

$\Delta: \mathrm{C}(41-1487) \quad 0: \beta-\mathrm{CaSiO}_{3}$

Note that the heat treatment of spray-pyrolyzed powder was conducted at $800^{\circ} \mathrm{C}$ for $10 \mathrm{~min}$ in air. 


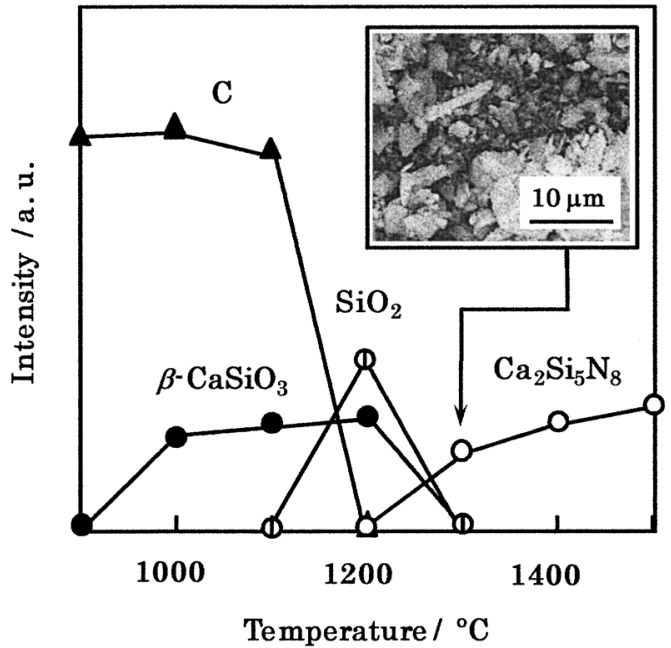

Figure 5 Phase changes during the $\mathrm{CRN}$ treatment ( $m: 1.5)$ of oxide powder prepared using SP(CS), together with typical FE-SEM micrograph

O: $\mathrm{Ca}_{2} \mathrm{Si}_{5} \mathrm{~N}_{8}\left(2 \theta=35.2^{\circ} ;\right.$ JCPDS 82-2489)

(1): $\mathrm{SiO}_{2}\left(2 \theta=26.8^{\circ} ; 52-1425\right)$

- : $\beta-\mathrm{CaSiO}_{3}\left(2 \theta=29.90^{\circ}\right) \quad \boldsymbol{\Delta}: \mathrm{C}\left(2 \theta=26.60^{\circ}\right)$

Note that the spray-pyrolyzed powder was calcined at $800^{\circ} \mathrm{C}$ for 10 min in air, and that CRN treatment was conducted at each temperature for $2 \mathrm{~h}$ in $\mathrm{N}_{2}$ atmosphere.

the characteristic X-ray reflections of the compounds. Results are shown in Figure 5, together with FE-SEM micrograph. X-ray intensity of carbon started to decrease at $900^{\circ} \mathrm{C}$ and disappeared at $1200^{\circ} \mathrm{C}$. Although $\beta-\mathrm{CaSiO}_{3}$ and $\mathrm{SiO}_{2}$ were present in the temperature range of 900 to $1300^{\circ} \mathrm{C}$, only $\mathrm{Ca}_{2} \mathrm{Si}_{5} \mathrm{~N}_{8}$ existed above $1300^{\circ} \mathrm{C}$. FE-SEM micrograph of the powder heated at $1300^{\circ} \mathrm{C}$ for $4 \mathrm{~h}$ indicated the presence of the irregular-shaped particles with sizes of around 1-5 $\mu \mathrm{m}$.

The carbothermal reduction process based upon the above phase changes may be expressed as follows:

$$
2 \mathrm{CaO}+5 \mathrm{SiO}_{2}+12 \mathrm{C}+4 \mathrm{~N}_{2} \rightarrow \mathrm{Ca}_{2} \mathrm{Si}_{5} \mathrm{~N}_{8}+12 \mathrm{CO}
$$

Here $\beta-\mathrm{CaSiO}_{3}$ may be formed by the reaction of $\mathrm{CaO}$ with $\mathrm{SiO}_{2}$ (see Eq. (2)). It should be noted that the objective compound of $\mathrm{Ca}_{2} \mathrm{Si}_{5} \mathrm{~N}_{8}$ could be formed with the disappearance of $\mathrm{C}$, and that the single phase of $\mathrm{CaSi}_{5} \mathrm{~N}_{8}$ : $\mathrm{Eu}^{2+}$, i.e., $\left(\mathrm{Ca}_{0.99} \mathrm{Eu}_{0.01}\right)_{2} \mathrm{Si}_{5} \mathrm{~N}_{8}$, could be obtained at the carbothermal temperature as low as $1300^{\circ} \mathrm{C}$. Unfortunately, no regular-shaped particles could be obtained by the utilization of SP(CS).

\subsection{Preparation of $\left(\mathrm{Ca}_{0.99} \mathrm{Eu}_{0.01}\right)_{2} \mathrm{Si}_{5} \mathrm{~N}_{8}$ from $\mathrm{SP}(\mathrm{SN})$}

The single phase of $\mathrm{Ca}_{2} \mathrm{Si}_{5} \mathrm{~N}_{8}$ could be successfully prepared but the particle morphology was irregular by using the combined techniques of USP and CRN at temperature as low as $1300^{\circ} \mathrm{C}$. We considered that the active mass transfer during the drastic substitution of oxygen for nitrogen in the CRN operation of the oxide
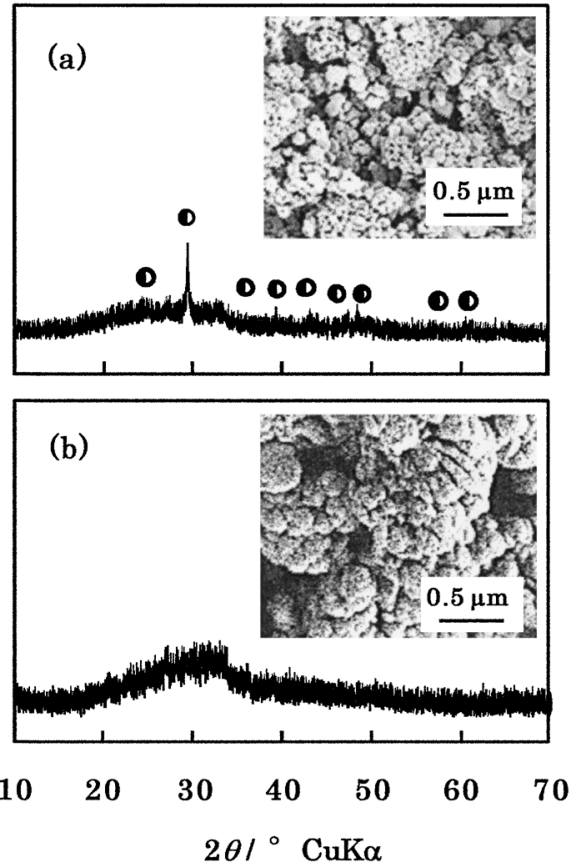

Figure $6 \mathrm{XRD}$ patterns of the powders obtained by the spray pyrolysis of (a) $\mathrm{SP}(\mathrm{SN}-1.0)$ and (b) $\mathrm{SP}(\mathrm{SN}-0.5)$ at $600^{\circ} \mathrm{C}$, together with FE-SEM micrographs

D: $\mathrm{CaCO}_{3}$ (JCPDS, 47-1743)

powder may be one of the reasons not to control the particle morphology. Then we replaced the CS with $\mathrm{SN}$ in the spraying solution, from the prospect that the gradual CRN treatment may be expected to control the particle morphology, as well as the formation of $\left(\mathrm{Ca}_{0.99} \mathrm{Eu}_{0.01}\right)_{2} \mathrm{Si}_{5} \mathrm{~N}_{8}$. Figure 6 shows the typical XRD patterns of spraypyrolyzed powder (SP(SN-1.0) and SP(SN-0.5)), together with FE-SEM micrographs. XRD pattern of the powder obtained by the spray pyrolysis of $\mathrm{SP}(\mathrm{SN}-1.0)$ indicated the presence of amorphous materials (broad background) and $\mathrm{CaCO}_{3}$. The resulting powder was composed of agglomerates with sizes of around $0.2 \mu \mathrm{m}$ (Figure 6(a)). On the other hand, XRD pattern of the powder obtained by the spray pyrolysis of SP(SN-0.5) indicated the presence of amorphous materials (broad background). The powder was composed of agglomerates with sizes of around $0.3 \mu \mathrm{m}$ (Figure 6(b)).

The noted phenomenon regarding the crystalline phase of the powder obtained by the spray pyrolysis of $\mathrm{SP}(\mathrm{SN}-1.0)$ was the formation of $\mathrm{CaCO}_{3}$. When the acidic solution containing $\mathrm{Ca}\left(\mathrm{NO}_{3}\right)_{2}, \mathrm{Si}_{3} \mathrm{~N}_{4}$ and $\mathrm{Eu}\left(\mathrm{NO}_{3}\right)_{3}$ was spray-pyrolyzed at $600^{\circ} \mathrm{C}$, the retarded reaction of $\mathrm{Ca}^{2+}$ with $\mathrm{Si}_{3} \mathrm{~N}_{4}$ may preferentially form $\mathrm{CaCO}_{3}$, due to the reaction of $\mathrm{Ca}^{2+}$ with $\mathrm{CO}_{2}$ present in the acidic solution. The formation of $\mathrm{CaCO}_{3}$ seems to be restricted by the utilization of dilute solution of $\mathrm{SP}(\mathrm{SN}-0.5)$, i.e., the retarded reaction of $\mathrm{Ca}^{2+}$ with $\mathrm{CO}_{2}$.

Then CRN operation of the powder obtained by the spray pyrolysis of $\mathrm{SP}(\mathrm{SN}-1.0)$ was conducted at a 


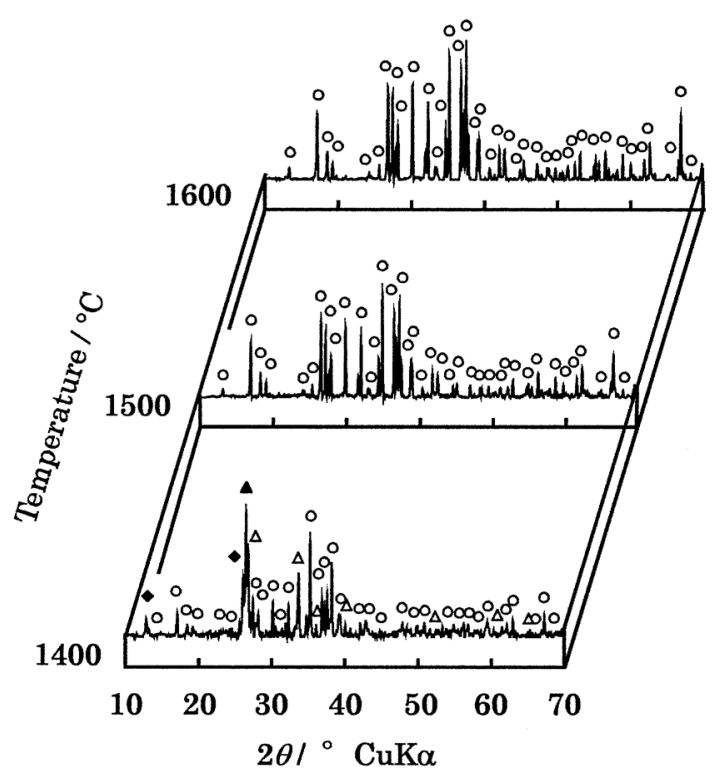

Figure 7 XRD patterns of the powders after the CRN treatment of the powder prepared by the spray pyrolysis of SP(SN-0.5)

$\mathrm{O}: \mathrm{Ca}_{2} \mathrm{Si}_{5} \mathrm{~N}_{8} \quad \boldsymbol{\Delta}: \mathrm{C} \quad \triangle: \mathrm{Si}_{3} \mathrm{~N}_{4}$ (JCPDS 73-

1210), : unknown phase

Note that the CRN operation was conducted at each temperature for $2 \mathrm{~h}$ in $\mathrm{N}_{2}$ atmosphere, and that $m$ value was fixed at 1.5 .

temperature between 1300 and $1500^{\circ} \mathrm{C}$. The reaction products were $\mathrm{Ca}_{2} \mathrm{SiO}_{4}$ and unknown phases, as well as carbon. Thus no objective compound, $\mathrm{Ca}_{2} \mathrm{Si}_{5} \mathrm{~N}_{8}$, was obtained in the range of 1300 to $1500^{\circ} \mathrm{C}$. On the basis of the information obtained above, the CRN treatment of the powder obtained by the spray pyrolysis of $\mathrm{SP}(\mathrm{SN}-0.5)$ was conducted at a temperature between 1400 and $1600^{\circ} \mathrm{C}$. The XRD results obtained are shown in Figure 7. When the $\mathrm{CRN}$ treatment was conducted at $1400^{\circ} \mathrm{C}$ for $2 \mathrm{~h}$ in $\mathrm{N}_{2}$ atmosphere, the objective compound of $\mathrm{Ca}_{2} \mathrm{Si}_{5} \mathrm{~N}_{8}$, as well as $\mathrm{C}, \mathrm{Si}_{3} \mathrm{~N}_{4}$ and unknown phase, was found to form. When the $\mathrm{CRN}$ operation was conducted at 1500 and $1600^{\circ} \mathrm{C}$, only $\mathrm{Ca}_{2} \mathrm{Si}_{5} \mathrm{~N}_{8}$ was detected from the powder.

The reaction to form $\mathrm{Ca}_{2} \mathrm{Si}_{5} \mathrm{~N}_{8}$ is shown as the following route:

$$
6 \mathrm{CaO}+5 \mathrm{Si}_{3} \mathrm{~N}_{4}+2 \mathrm{~N}_{2}+6 \mathrm{C} \rightarrow 3 \mathrm{Ca}_{2} \mathrm{Si}_{5} \mathrm{~N}_{8}+6 \mathrm{CO}
$$

The typical SEM micrographs of these powders are shown in Figure 8. When the CRN treatment was conducted at $1400^{\circ} \mathrm{C}$, the particle sizes were around $1 \mu \mathrm{m}$. The particle size increased with increasing $\mathrm{CRN}$ temperature and attained approximately $2 \mu \mathrm{m}$ at $1500^{\circ} \mathrm{C}$ and $3 \mu \mathrm{m}$ at $1600^{\circ} \mathrm{C}$. It should be noted that no marked agglomeration of particles was found in the resulting powder, and that the particle sizes of $\mathrm{Ca}_{2} \mathrm{Si}_{5} \mathrm{~N}_{8}$ prepared by the carbothermal reduction reported so far was approximately $20 \mu \mathrm{m}^{6}$. . The present particle sizes were about $1 / 10$, compared to the previous report ${ }^{6}$.

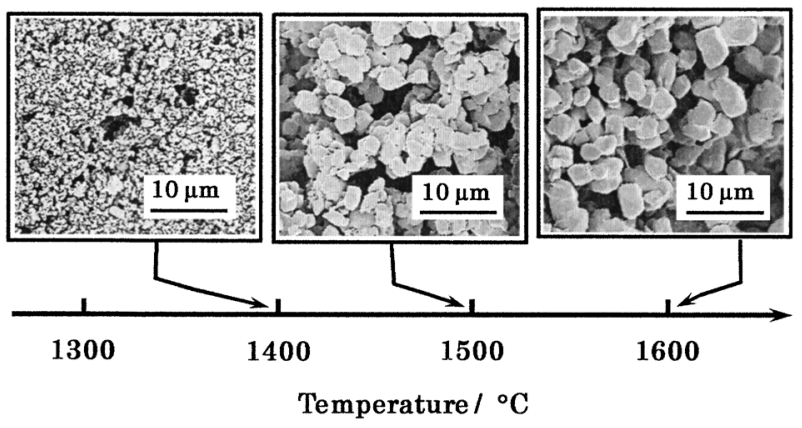

Figure 8 FE-SEM micrographs of the powder after the spray pyrolysis of SP(SN-0.5) and subsequent CRN treatment

Note that the CRN treatment was conducted at each temperature for $2 \mathrm{~h}$, and that $m$ value was fixed at 1.5 .

The chemical compositions of resulting powders, i.e., (i) the conventional solid state reaction (SSR) among $\mathrm{CaCO}_{3}$, $\mathrm{Si}_{3} \mathrm{~N}_{4}$ and $\mathrm{Eu}_{2} \mathrm{O}_{3}$ and $\mathrm{CRN}$ treatment at $1550^{\circ} \mathrm{C}$ for $2 \mathrm{~h}$, (ii) USP of the SP(CS) and subsequent CRN treatment at $1300^{\circ} \mathrm{C}$ for $2 \mathrm{~h}$, and (iii) USP of the SP(SN-0.5) and subsequent $\mathrm{CRN}$ treatment at $1500^{\circ} \mathrm{C}$ for $2 \mathrm{~h}$, are shown in Table 2. The chemical compositions of these powders measured by SEM/EDX were in good accordance with theoretical value. Overall, we successfully prepared the $\mathrm{Ca}_{2} \mathrm{Si}_{5} \mathrm{~N}_{8}$ through the combination of USP and CRN techniques, as well as the conventional SSR, and particle shape could be controlled by the utilization of spray pyrolysis of $\mathrm{SP}(\mathrm{SN}-0.5)$.

\subsection{Luminescence properties of $\left(\mathrm{Ca}_{0.99} \mathrm{Eu}_{0.01}\right)_{2} \mathrm{Si}_{5} \mathrm{~N}_{8}$}

In Section 3.1 and 3.2, we have successfully prepared the single phase of $\mathrm{Eu}^{2+-}$ doped $\mathrm{Ca}_{2} \mathrm{Si}_{5} \mathrm{~N}_{8}$ powder. Then the excitation and emission spectra were examined using the powders obtained by the spray pyrolysis of SP(CS) and $\mathrm{SP}(\mathrm{SN}-0.5)$. The results are shown in Figure 9, together with the case of powder obtained by the conventional CRN technique for comparison. These compounds showed a broad excitation band from 200 to $500 \mathrm{~nm}$ and emission at about $590 \mathrm{~nm}$. The $\mathrm{Eu}^{2+}$ ion is responsible for the excitation band $\left(4 \mathrm{f}^{7} \rightarrow 4 \mathrm{f}^{6} \mathrm{~b} \mathrm{~d}\right)$, and the emission peak is assigned to

Table 2 Chemical compositions (determined by SEM/EDX) of the powders prepared by the CRN treatment of various oxide/nitride powders

\begin{tabular}{|c|c|c|c|}
\hline \multirow{2}{*}{$\begin{array}{c}\text { Sample } \\
\text { Code }\end{array}$} & $\mathrm{Ca}$ & $\mathrm{Si}$ & $\mathbf{C a}$ \\
\hline & mol & mol & Si \\
\hline SSR $^{a)}$ & 28.6 & 71.1 & 0.402 \\
\hline SP(CS) & 28.7 & 71.3 & 0.403 \\
\hline $\mathrm{SP}(\mathrm{SN}-0.5)$ & 28.5 & 71.5 & 0.399 \\
\hline TV b) & 28.4 & 71.6 & 0.396 \\
\hline
\end{tabular}

a) Solid State Reaction b) Theoretical Value 


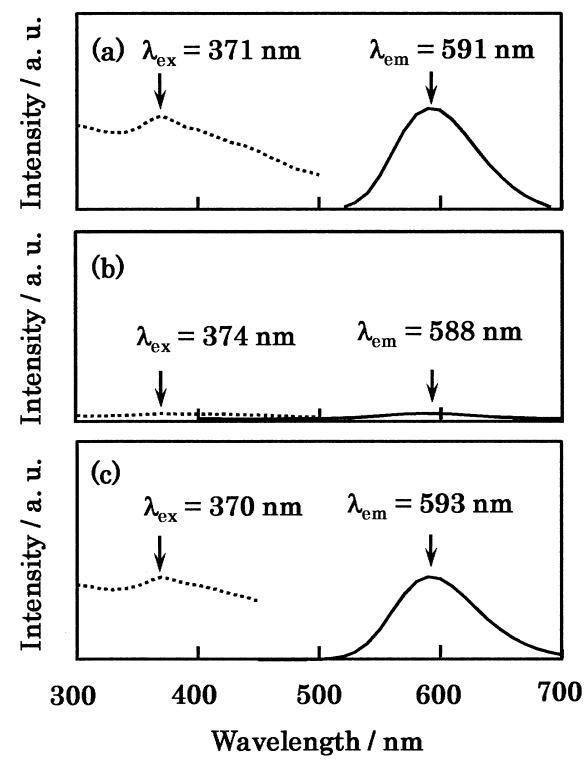

Figure 9 Excitation and emission spectra of various $\left(\mathrm{Ca}_{0.99} \mathrm{Eu}_{0.01}\right)_{2} \mathrm{Si}_{5} \mathrm{~N}_{8}$ powders

(a) Conventional SSR-CRN techniques $\left(1550^{\circ} \mathrm{C}, 2 \mathrm{~h}, \mathrm{~N}_{2}\right.$ atmosphere, $\left.m=1.5\right)$

(b) USP-CRN techniques (SP(CS); $1300^{\circ} \mathrm{C} 2 \mathrm{~h}$, $\mathrm{N}_{2}$ atmosphere, $\left.m=1.5\right)$

(c) USP-CRN techniques (SP(SN); $1500^{\circ} \mathrm{C} 2 \mathrm{~h}$, $\mathrm{N}_{2}$ atmosphere, $m=1.5$ )

the allowed $4 \mathrm{f}^{6} 5 \mathrm{~d}^{1} \rightarrow 4 \mathrm{f}^{7}$ transition of $\mathrm{Eu}^{2+}$ ion. Li et $\mathrm{al}^{4)}$ reported that the emission peak of $\left(\mathrm{Ca}_{1-x} \mathrm{Eu}_{x}\right)_{2} \mathrm{Si}_{5} \mathrm{~N}_{8}$ for the excitation at $465 \mathrm{~nm}$ shifts from 605 to $615 \mathrm{~nm}$ with increasing $x$ from 0.01 to 0.07 . On the other hand, Piao et al. $\left.{ }^{6}\right)$ reported that the emission peak of $\left(\mathrm{Ca}_{1-x} \mathrm{Eu}_{x}\right)_{2} \mathrm{Si}_{5} \mathrm{~N}_{8}$ prepared by CRN shifts from 596 to $612 \mathrm{~nm}$ with increasing $x$ from 0.005 to 0.20 . Such lowering of the emission peaks' wavelength must be associated not only with Stokes shift, covalency and crystal-field splitting of $5 \mathrm{~d}$ levels of $\mathrm{Eu}^{2+}$, but also with particle size, lattice defects, etc. The understanding of this phenomenon, however, needs further investigation. It is noted that the emission of $\left(\mathrm{Ca}_{1 \cdot x} \mathrm{Eu}_{x}\right)_{2}$ $\mathrm{Si}_{5} \mathrm{~N}_{8}$ may be tuned by controlling the amount of $\mathrm{Eu}^{2+4) 6}$.

The relative emission intensity of ( $\left.\mathrm{Ca} 0.99 \mathrm{Eu}_{0.01}\right)_{2} \mathrm{Si}_{5} \mathrm{~N}_{8}$ prepared using $\mathrm{SN}(=0.452)$ was higher than the case of the utilization of $\mathrm{CS}(=0.0371)$, and comparable to the case of SSR/CRN (=0.494). The low relative intensity of $\left(\mathrm{Ca}_{0.99} \mathrm{Eu}_{0.01}\right)_{2} \mathrm{Si}_{5} \mathrm{~N}_{8}$ prepared using the $\mathrm{CS}$ may be associated with the poor crystallinity based upon the lower CRN temperature but is expected to improve when the CRN operation is conducted at higher temperature.

\section{Conclusion}

The conditions for the preparation of regular-shaped $\mathrm{Eu}^{2+-}$ doped (Ca0.99Eu0.01) ${ }_{2} \mathrm{Si}_{5} \mathrm{~N}_{8}$ powder were examined by the CRN treatment of oxide/nitride powder prepared by USP. The objective compound ( $\left.\mathrm{Ca}_{0.99} \mathrm{Eu}_{0.01}\right)_{2} \mathrm{Si}_{5} \mathrm{~N}_{8}$ could be obtained when $\mathrm{CS}$ and $\mathrm{SN}$ were used as silicon sources.
The results obtained were summarized as follows:

(i) The solution containing $0.057 \mathrm{~mol} \cdot \mathrm{dm}^{-3} \mathrm{Ca}\left(\mathrm{NO}_{3}\right)_{2}$, $0.140 \mathrm{~mol} \cdot \mathrm{dm}^{-3} \mathrm{CS}$ and $5.71 \times 10^{-4} \mathrm{Eu}\left(\mathrm{NO}_{3}\right)_{3}$ was spray-pyrolyzed at $600^{\circ} \mathrm{C}$, and then the resulting powder was heat-treated at $800^{\circ} \mathrm{C}$ for $10 \mathrm{~min}$. Single phase of (Ca0.99Eu.01 $)_{2} \mathrm{Si}_{5} \mathrm{~N}_{8}$ could be obtained when the CRN $(m: 1.5)$ of spray-pyrolyzed/heat-treated oxide powder was conducted at $1300^{\circ} \mathrm{C}$ for $2 \mathrm{~h}$.

(ii) The solution containing $0.0285 \mathrm{~mol} \cdot \mathrm{dm}^{-3} \mathrm{Ca}\left(\mathrm{NO}_{3}\right)_{2}$, $0.070 \mathrm{~mol} \cdot \mathrm{dm}^{-3} \mathrm{SN}$ and $2.855 \times 10^{-4} \mathrm{~mol} \cdot \mathrm{dm}^{-3}$ $\mathrm{Eu}\left(\mathrm{NO}_{3}\right)_{3}$ was spray-pyrolyzed at $600^{\circ} \mathrm{C}$, and then the CRN ( $m=1.5)$ of spray-pyrolyzed oxide/nitride powder was conducted at $1500^{\circ} \mathrm{C}$ for $2 \mathrm{~h}$ to obtain (Ca0.99Eu0.01 ${ }_{2} \mathrm{Si}_{5} \mathrm{~N}_{8}$. This powder was composed of regular-shaped particles with sizes of $2-3 \mu \mathrm{m}$. The excitation and emission peaks of this powder appeared at around 370 and $590 \mathrm{~nm}$, respectively, showing the emission of orange light; the relative emission intensities of $\left(\mathrm{Ca}_{0.99} \mathrm{Eu}_{0.01}\right)_{2} \mathrm{Si}_{5} \mathrm{~N}_{8}$ prepared using SN was much higher than the case of CS.

\section{References}

(1) Xie, R.-J. and Hirosaki, N.: Silicon-based oxynitride and nitride phosphors for white LEDs-a review, Scie nce Technology Advanced Materials, Vol. 8(7-8), pp. 588-600 (2007).

(2) Xie, R.-J., Hirosaki, N., Sakamura, K., Yamamuro, Y. and Mitomo, M: $\mathrm{Eu}^{2+-}$ doped $\mathrm{Ca}^{-} \alpha-\mathrm{SiAlON}$ a yellow phosphor for white light-emitting diodes, Applied Physics Letter, Vol. 84 (26), pp. 5404-5406 (2004).

(3) Horikawa, T., Piao X., Fujitani, M., Hanzawa, H. and Machida, K.: Preparation of $\mathrm{Sr}_{2} \mathrm{Si}_{5} \mathrm{~N}_{8}: \mathrm{Eu}^{2+}$ phosphors using various novel reducing agents and their luminescent properties, Materials Science Engineering, Vol. 1, pp. 012024-1-6 (2009).

(4) Li, Y. Q., Van Steen, J. E. J., Van Krevel J. W. H., Botty, G., Delsing, A. C. A.., DIsalvo, F. J., De with G. and Hintzen, H. T.: Luminescence properties of redemitting $\mathrm{M}_{2} \mathrm{Si}_{5} \mathrm{~N}_{8}: \mathrm{Eu}^{2+}(\mathrm{M}=\mathrm{Ca}, \mathrm{Sr}, \mathrm{Ba})$ LED conversion phosphors, J. Alloys and Compounds., Vol. 417(1-2), pp. 273-279 (2006).

(5) Li, H. L, Xie, R. J., Hirasaki, N. and Takeda, T.: Synthesis and luminescence properties of orangered-emitting $\mathrm{M}_{2} \mathrm{Si}_{5} \mathrm{~N}_{8}: \mathrm{Eu}^{2+}(\mathrm{M}=\mathrm{Ca}, \mathrm{Sr}, \mathrm{Ba})$ light-emitting diode conversion phosphors by a simple nitridation of $\mathrm{MSi}_{2}, \mathrm{~J}$. Applied Ceramic Technology, Vol.6(4), pp. 459-464 (2009).

(6) Piao X., Horikawa, T., Fujitani, M., Hanazawa, H. and Machida, K: Photoluminescence properties of $\mathrm{Ca}_{2} \mathrm{Si}_{5} \mathrm{~N}_{8}: \mathrm{Eu}^{2+}$ nitride phosphor prepared by carbothermal reduction and nitridation method, Chemistry of Letters, Vol35(3), pp. 334-335 (2006).

(7) Lin, S. E., Borgohain, K. and Wei, W. C.: Praseodymium-doped photo-luminescent strontium 
indate nanoparticles by ultrasonic spray pyrolysis, J. American Ceramic Society, Vol. 89(10), pp. 32663269 (2006).

(8) Itatni, K., Umeda, T., Musha, Y. and Ian J. Davies, I. J.: Microstructures of spherical calcium-phosphate agglomerates prepared by spray pyrolysis and freeze-drying techniques, Phosphorous Research Bulletin, Vol. 20, pp. 47-60 (2006).

(9) Roh, H. S., Kang, Y. C., Lee, C. H., Park, H. D. and Park, S. B.: Morphological control of $\mathrm{Zn}_{2} \mathrm{SiO}_{4}: \mathrm{Mn}$ phosphor particles by adding citric acid in spray pyrolysis process, Japanese J. Applied Physics Part 1, Vol. 42(6A), pp. 3429-3433 (2003).

(10) Kang, Y. C., Roh, H. S., Seo, D. J. and Park, S. B.: The effect of metal carbonate fluxes on the crystallinity, morphology, and photoluminescence characteristics of $\mathrm{Y}_{2} \mathrm{O}_{3}: \mathrm{Eu}$ phosphor in spray pyrolysis, J. Materials Science Letters, Vol. 19(4), $1225-1227$ (2000).

(11) Lang, R. J.: Ultrasonic Atomization of Liquids, J. Acoustical Society of America, Vol. 34(1), pp. 6-8 (1962). 